\title{
Arsenic(III) removal from aqueous solution by raw and zinc- loaded pine cone biochar: equilibrium, kinetics, and thermodynamics studies
}

\author{
N. Van Vinh $\cdot$ M. Zafar $\cdot$ S. K. Behera $\cdot$ \\ H.-S. Park
}

Received: 31 July 2013/Revised: 12 December 2013/ Accepted: 11 January 2014/Published online: 29 January 2014

(C) Islamic Azad University (IAU) 2014

\begin{abstract}
The potential of raw pine cone (PC) biochar and its modified form (Zn-loaded biochar) was evaluated for the removal of trivalent arsenic [As(III)] from the aqueous solution. The influence of treatment of PC biochar with $\mathrm{Zn}\left(\mathrm{NO}_{3}\right)_{2}$ on the physico-chemical properties of biochar was examined using elemental analyzer, surface area analyzer, thermo-gravimetric analyzer, Fourier transform infrared spectroscopy, and scanning electron microscopy. Experimental results revealed that the removal of As(III) was almost consistent $(66.08 \pm 3.94$ and $87.62 \pm 3.88 \%$ on raw and $\mathrm{Zn}$-loaded biochar, respectively) over an acidic $\mathrm{pH}$ range of 2-4 as a consequence of high affinity between the positively charged biochar surface and the predominant arsenic species $\left(\mathrm{H}_{3} \mathrm{AsO}_{3}\right.$ and $\left.\mathrm{H}_{2} \mathrm{AsO}_{4}{ }^{-}\right)$, followed by a decrease with increase in $\mathrm{pH}$ in the range of 4-12. Langmuir isotherm model was well fitted to the experimental equilibrium data $\left(R^{2}=0.93\right)$ rendering the maximum adsorption capacity of 5.7 and $7.0 \mu \mathrm{g} \mathrm{g}^{-1}$ on raw and $\mathrm{Zn}$ loaded PC biochar, respectively. The adsorption of As(III) was well represented by pseudo-second order with reaction rate constant $\left(k_{2}\right)$ of 0.040 and $0.282 \mathrm{mg} \mathrm{g}^{-1}$ min on raw and zinc-loaded PC biochar, respectively, and was mainly controlled by boundary layer diffusion followed by some
\end{abstract}

N. Van Vinh · H.-S. Park $(\bowtie)$

Department of Civil and Environmental Engineering, University of Ulsan, Ulsan, Republic of Korea

e-mail: parkhs@ulsan.ac.kr

M. Zafar $\cdot$ S. K. Behera $\cdot$ H.-S. Park

Center for Clean Technology and Resource Recycling,

University of Ulsan, Ulsan, Republic of Korea

S. K. Behera

Chemical Engineering Department, GMR Institute of

Technology, Rajam, Srikakulam Dist 532127, AP, India extent of intra-particle diffusion. The adsorption process was spontaneous with Gibb's free energy $\left(\Delta G^{\circ},-4.42 \pm\right.$ 0.72 and $\left.-11.86 \pm 1.78 \mathrm{~kJ} \mathrm{~mol}^{-1}\right)$ and exothermic in nature with enthalpy $\left(\Delta H^{\circ}, 13.25\right.$ and $\left.31.10 \mathrm{~kJ} \mathrm{~mol}^{-1}\right)$ and entropy $\left(\Delta S^{\circ}, 0.058\right.$ and $\left.0.141 \mathrm{~kJ} \mathrm{~mol}^{-1} \mathrm{~K}^{-1}\right)$ for raw and zinc-loaded adsorbent, respectively.

Keywords Pine cone - Biochar - Arsenic removal . Equilibrium $\cdot$ Kinetics $\cdot$ Thermodynamic

\section{Introduction}

Groundwater contamination by heavy metals has been recognized as a global environmental threat that has emanated largely due to the increase in effluent discharge from the mining and electroplating industries. These effluents contain high levels of cadmium, mercury, copper, arsenic, and lead among which arsenic (As) has been considered as the most toxic heavy metal to aquatic flora and fauna even in very low concentrations (Mohan et al. 2007). In the aquatic environment, it exists in different forms such as arsenious $\left(\mathrm{H}_{3} \mathrm{AsO}_{3}, \quad \mathrm{H}_{3} \mathrm{AsO}_{3}, \mathrm{H}_{3} \mathrm{AsO}_{3}{ }^{2-}\right)$, arsenic $\left(\mathrm{H}_{3} \mathrm{AsO}_{4}, \mathrm{H}_{3} \mathrm{AsO}^{4-}, \mathrm{H}_{3} \mathrm{AsO}_{4}{ }^{2-}\right)$, arsenites [As(III)], arsenates $[\mathrm{As}(\mathrm{V})]$, methylarsenic, dimethylarsinic acid, and arsine (Mohan and Pittman 2007). Its long-term exposure causes a variety of serious health issues such as dermal changes (pigmentation, hyperkeratoses, and ulceration), respiratory, neurological, cardiovascular, vomiting as well as results in the appearance of diverse type of cancer of skin, lung, bladder, and kidney (Guo et al. 2007; Mandal and Suzuki 2002; Kamsonlian et al. 2012). The toxicity of As exists greatly in its oxidation states $(-3,0,+3$, and +5 ), and the trivalent form [As(III)] is recognized as most hazardous state (Manju et al. 1998). The World Health 
Organization (WHO), the European Union (EU), and several countries including Japan, India, China, Bangladesh, and Vietnam have recommended its maximum contaminant level (MCL) of $10 \mu \mathrm{g} \mathrm{L}^{-1}$ in drinking water (Mohan and Pittman 2007; Urík et al. 2009; Mafu et al. 2013).

There are many technologies, viz. enhanced coagulation, membrane systems, ion exchange, adsorption, lime softening, and oxidation processes being available for the removal of arsenic from wastewater/drinking water (Ghanizadeh et al. 2010; Akter and Ali 2011). Among them, adsorption process is cost-effective, flexible, and easy to design and operate. Several types of absorbent including iron-containing granular activated carbon (GAC) (Gu et al. 2005), iron-containing fly ash (Yi et al. 2009), iron-impregnated AC (Ghanizadeh et al. 2010; Vaughan and Reed 2005), zirconium-loaded AC (Daus et al. 2004; Peraniemi et al. 1994), silver and copperimpregnated AC (Rajakovic 1992), and zinc-preloaded magnetite nanoparticle (Yang et al. 2010) have been used for the removal of arsenic from the water/wastewater system. In order to enhance the process economy, the production of adsorbents from low-cost renewable biomass is usually encouraged as the surface modification of these adsorbents can further enhance the adsorptive removal of toxicants.

Pine cone (PC) is an agricultural waste which is derived in large quantity as an inexpensive biomass from the pine plantations made for pulp and paper industry (Ofomaja et al. 2009; Ayrilmis et al. 2009). The surface of PC contains various functional groups such as alcohols and aldehydes in its cellulose, hemicelluloses, and lignin fractions, which make it suitable for a series of chemical reactions (condensation, etherification, and copolymerization) and surface modifications (Benyoucef and Amrani 2011). Many studies have reported the utilization of PC as an effective biosorbent for the removal of $\mathrm{Cu}$ (II) and $\mathrm{Pb}$ (II) (Ofomaja et al. 2010), $\mathrm{Cd}(\mathrm{II})$ and $\mathrm{Pb}(\mathrm{II})$ (Argun et al. 2008), Cr(IV) (Ucun et al. 2008), phosphate ions (Benyoucef and Amrani 2011), textile dyes (Mahmoodi et al. 2011), phenol (Vazquez et al. 2006), and anionic surfactant sodium dodecyl sulfate (Sen et al. 2012).

Biochar is derived from thermal degradation of different organic materials (crop residue, forest by-product, and sewage sludge) and has been recommended as a multifunctional adsorbent for the removal of organic pollutants and heavy metals (Regmi et al. 2012). The difference in the adsorption behavior of biosorbent and biochar is mainly due to the differences in its physico-chemical properties like porosity, surface area, pore structure, chemical/elemental composition, and ash content (Varol and Putun 2012).

To the best of our knowledge, raw and chemically modified (Zn-loaded) PC biochar has not been exploited before for the removal of $\mathrm{As}(\mathrm{III})$ from the wastewater/ drinking water. In this study, the adsorption potential of raw and modified PC biochar for the removal of As(III) from the aqueous solution was evaluated through a series of batch adsorption experiments. In order to gain an indepth understanding of adsorption mechanism of As(III) onto raw and modified biochar, equilibrium isotherms, kinetics, and thermodynamic studies have been extensively carried out. Besides, the physico-chemical properties of the raw and modified PC biochars were examined using elemental analyzer, surface area analyzer, thermo-gravimetric analyzer, Fourier transform infrared spectroscopy, and scanning electron microscopy.

\section{Materials and methods}

Preparation of raw and Zn-loaded PC biochar

Pine cones were collected from the pine trees located in the campus of University of Ulsan, Korea. In order to remove the impurities, the collected pine cones were washed with deionized water and dried in an oven at $110{ }^{\circ} \mathrm{C}$ for $24 \mathrm{~h}$. After drying, the material was crushed and sieved through a $1.18 \mathrm{~mm}$ standard mesh. The pyrolysis of fine PC powder $(1.18 \mathrm{~mm})$ was carried out in a fixed bed reactor having dimension of $45 \mathrm{~cm} \times 10 \mathrm{~cm}$ (length $\times$ diameter). The powder samples were placed in the reactor at $500{ }^{\circ} \mathrm{C}$ temperature for $1 \mathrm{~h}$ with the purging of nitrogen at a flow rate of $0.1 \mathrm{~m}^{3} \mathrm{~h}^{-1}$. Finally, the pyrolized samples were washed three times with deionized water and dried in an oven at $90{ }^{\circ} \mathrm{C}$ overnight.

In order to prepare the metal-loaded PC biochar, $10 \mathrm{~g}$ of dried PC biochar was mixed with $100 \mathrm{~mL}$ of $\mathrm{Zn}\left(\mathrm{NO}_{3}\right)_{2} \cdot 6 \mathrm{H}_{2} \mathrm{O}$ precursor solution. The mixture was stirred at room temperature $\left(25^{\circ} \mathrm{C}\right)$ for $12 \mathrm{~h}$. After filtration and washing, the Zn-loaded PC biochar was dried in an oven at $110{ }^{\circ} \mathrm{C}$ overnight. More details of impregnation method are available elsewhere (Rajakovic 1992; Ning et al. 2013).

\section{Characterization of raw and Zn-loaded biochar}

Elemental composition $(\mathrm{C}, \mathrm{H}, \mathrm{N}, \mathrm{S}$, and $\mathrm{O})$ of biochar was determined by an elemental analyzer (Flash 2000, Thermo Scientific, Milan, Italy). Thermo-gravimetric (TG/DTA) analyzer (TA Q50 instrument, USA) was used for the determination of thermal properties of biochar, while the functional group analysis was conducted by a Fourier transform infrared spectrometer (Nicolet 380, Thermo Electron Co., USA) over $400-4,000 \mathrm{~cm}^{-1}$ using the $\mathrm{KBr}$ pellet technique. The surface physical morphology was examined using a field emission scanning electron 
microscope (FE-SEM) (JSM-6500F, JEOL, Tokyo, Japan) operating at $10 \mathrm{kV}$. The surface porosity was measured by an ASAP 2020-Micromeritics apparatus, USA, and the specific surface area and pore volume were determined using Brunauer-Emmett-Teller (BET) method.

\section{Batch adsorption experiments}

Batch adsorption experiments were conducted using known amount of PC biochar with $50 \mathrm{~mL}$ of As(III) solution in 100-ml Erlenmeyer flasks. $\mathrm{pH}$ of the solution was adjusted by using $0.1 \mathrm{M}$ standard solution of $\mathrm{HCl} / \mathrm{NaOH}$. The flasks were placed on a thermostat shaker stirred at $120 \mathrm{rpm}$ and at ambient temperature $\left(25^{\circ} \mathrm{C}\right)$. After a specified time, suspension was filtered and analyzed for residual As(III) concentration by atomic absorption spectrophotometer (model AA240-2004, Varian, USA). Each experiment was conducted in duplicate under identical conditions and the average values were reported. The effect of $\mathrm{pH}$ on adsorption capacity was examined by varying the $\mathrm{pH}$ from 2 to 12 with the adsorbent and adsorbate doses of $10 \mathrm{~g} \mathrm{~L}^{-1}$ and $100 \mu \mathrm{g} \mathrm{L}^{-1}$, respectively. In order to study the adsorption isotherm equilibrium, the experiments were conducted at initial concentrations of As(III) varying between 50 and $200 \mu \mathrm{g} \mathrm{L}^{-1}$, at the adsorbent dose of $10 \mathrm{~g} \mathrm{~L}^{-1}$. The kinetics of adsorption process was determined using the experimental data with adsorbent and adsorbate concentrations of $10 \mathrm{~g} \mathrm{~L}^{-1}$ and $100 \mu \mathrm{g} \mathrm{L}^{-1}$, respectively. The samples were taken at regular interval of $1 \mathrm{~h}$ to determine the residual concentration of $\mathrm{As}(\mathrm{III})$ in the aqueous solution.

The amount of adsorption per gram of adsorbent, $q\left(\mathrm{mg} \mathrm{g}^{-1}\right)$, was calculated by:

$q=\frac{\left(C_{0}-C\right) V}{W}$

where $C_{0}$ and $C$ are the concentrations of adsorbate in the solution at time zero and any time ' $t$,' respectively, $V$ is the working volume, and $W$ is the mass of adsorbent dose.

\section{Adsorption isotherms}

The adsorption process is usually described through isotherms, i.e., the amount of adsorbate on the adsorbent $\left(q_{\mathrm{e}}\right)$ as a function of its concentration $\left(C_{\mathrm{e}}\right)$ at constant temperature. The Langmuir model equation is expressed as:

$\frac{C_{\mathrm{e}}}{q_{\mathrm{e}}}=\frac{1}{b q_{\max }}+\frac{C_{\mathrm{e}}}{q_{\max }}$

where $C_{e}$ is the concentration of As(III) in solution (mg L $\mathrm{m}^{-1}$ ) at equilibrium, $q_{e}$ is the maximum As(III) uptake $\left(\mathrm{mg} \mathrm{g}^{-1}\right)$, and $b$ is the Langmuir equilibrium constant related to the free energy of adsorption and is the measure of adsorption affinity or heterogeneity. $q_{\max }$ is the maximum amount of $\mathrm{As}(\mathrm{III})$ per gram of adsorbent to form a complete monolayer on the surface. The Langmuir constants $b$ and $q_{\max }$ are calculated from the slope and intercept of $C_{\mathrm{e}} / q_{\mathrm{e}}$ versus $C_{\mathrm{e}}$.

The Freundlich model is an empirical model and is described by the equation:

$\log q_{\mathrm{e}}=\log K_{\mathrm{F}}+\frac{1}{n} \log C_{\mathrm{e}}$

where $K_{\mathrm{F}}$ is the measure of the adsorption capacity and $n$ is a measure of the adsorption intensity.

\section{Kinetic modeling}

Three kinetic models, namely pseudo-first-order, pseudosecond-order, and intra-particle diffusion models were used to analyze and determine the suitable kinetic parameters. The pseudo-first-order kinetic model is described by:

$\log \left(q_{\mathrm{e}}-q_{\mathrm{t}}\right)=\log q_{\mathrm{e}}-\frac{k_{1}}{2.303} t$

where $k_{1}\left(\mathrm{mg} \mathrm{g}^{-1} \mathrm{~min}\right)$ is pseudo-first-order adsorption rate constant that was obtained from the slopes of the linear plots of $\log \left(q_{\mathrm{e}}-q_{\mathrm{t}}\right)$ versus $t, q_{\mathrm{e}}$ and $q_{\mathrm{t}}$ are the amounts of adsorbate that adsorbed at equilibrium time, and time ' $t$,' respectively.

The pseudo-second-order chemisorption kinetic model is given as:

$\frac{t}{q_{\mathrm{t}}}=\frac{1}{k_{2} q_{\mathrm{e}}^{2}}+\frac{1}{q_{\mathrm{e}}} t$

where $k_{2}\left(\mathrm{mg} \mathrm{g}^{-1} \mathrm{~min}\right)$. is pseudo-second-order adsorption rate constant and can be obtained from the plot of $t / q_{\mathrm{t}}$ against $t$.

In order to identify the diffusion mechanism in an adsorption process, intra-particle diffusion model was considered. It helps in understanding the rate controlling step affecting the kinetics and to figure out the degree of boundary layer control. It is represented by the following equation:

$q_{\mathrm{t}}=k_{\mathrm{p}} t^{1 / 2}+c$

where $k_{\mathrm{p}}$ and $c$ are the intra-particle diffusion rate constant $\left(\mathrm{mg} \mathrm{g}^{-1} \min ^{1 / 2}\right)$ and the intercept, respectively.

\section{Thermodynamic studies}

In order to calculate the thermodynamic parameters such as Gibb's free energy $\left(\Delta G^{\circ}\right)$, entropy $\left(\Delta S^{\circ}\right)$, and enthalpy $\left(\Delta H^{\circ}\right)$ changes in the adsorption process of As (III) with raw and $\mathrm{Zn}$-loaded PC biochars, the following equation can be applied (Arias and Sen 2009; Karagöz et al. 2008). 
Table 1 Properties of raw and Zn-loaded pine cone biochar

\begin{tabular}{|c|c|c|c|}
\hline $\begin{array}{l}\text { S. } \\
\text { no. }\end{array}$ & Properties & $\begin{array}{l}\text { Raw PC } \\
\text { biochar }\end{array}$ & $\begin{array}{l}\text { Zn-loaded PC } \\
\text { biochar }\end{array}$ \\
\hline \multirow[t]{8}{*}{1} & \multicolumn{3}{|c|}{ Elemental composition (wt\%) } \\
\hline & $\mathrm{C}$ & 67.88 & 71.21 \\
\hline & $\mathrm{H}$ & 3.89 & 3.03 \\
\hline & $\mathrm{O}$ & 22.07 & 20.43 \\
\hline & $\mathrm{N}$ & 0.55 & 0.51 \\
\hline & $\mathrm{S}$ & $<0.01$ & $<0.01$ \\
\hline & $\mathrm{H} / \mathrm{C}$ & 0.06 & 0.04 \\
\hline & $\mathrm{O} / \mathrm{C}$ & 0.33 & 0.29 \\
\hline 2 & Bulk density $\left(\mathrm{kg} \mathrm{m}^{-3}\right)^{\mathrm{a}}$ & 216 & 256 \\
\hline 3 & Moisture $(\mathrm{wt} \%)^{\mathrm{b}}$ & 3.12 & 3.08 \\
\hline 4 & $\operatorname{Ash}(w t \%)^{b}$ & 2.13 & 2.14 \\
\hline 5 & Volatile matter $(\mathrm{wt} \%)^{\mathrm{b}}$ & 27.22 & 18.99 \\
\hline 6 & Fixed carbon $(\mathrm{wt} \%)^{\mathrm{b}}$ & 67.53 & 75.79 \\
\hline 7 & $\mathrm{pH}_{\mathrm{PZC}}^{\mathrm{c}}$ & 4.66 & 4.03 \\
\hline 8 & $\begin{array}{l}\text { BET surface area } \\
\left(\mathrm{m}^{2} \mathrm{~g}^{-1}\right)\end{array}$ & 6.60 & 11.54 \\
\hline 9 & $\begin{array}{l}\text { Micropore volume } \\
\left(\mathrm{cm}^{3} \mathrm{~g}^{-1}\right)\end{array}$ & 0.016 & 0.028 \\
\hline
\end{tabular}

a Tamping procedure, Ofomaja et al. (2010)

b Modified thermal analysis, Ahmad et al. (2012)

c pH drift, Muniz et al. (2009)

$\Delta G^{\circ}=\Delta H^{\circ}-T \Delta S^{\circ}$

$\log \left(\frac{q_{\mathrm{e}}}{C_{\mathrm{e}}}\right)=\frac{\Delta S^{\circ}}{2.303 R}+\frac{-\Delta H^{\circ}}{2.303 R T}$

where $q_{\mathrm{e}}$ is the amount of arsenic adsorbed per unit mass of adsorbent $\left(\mathrm{mg} \mathrm{g}^{-1}\right), C_{\mathrm{e}}$ is the equilibrium concentration (mg L $\left.\mathrm{m}^{-1}\right), R$ is the gas constant $\left(8.314 \mathrm{~J} \mathrm{~mol}^{-1} \mathrm{~K}^{-1}\right)$, and $T$ is temperature in degree Kelvin.

\section{Results and discussion}

Physico-chemical characterization of PC biochar

As shown in Table 1, the elemental composition of PC biochar mainly consists of 67.88 and $22.07 \mathrm{wt} \%$ of carbon and oxygen, respectively. The molar ratios of these elements were used to estimate the aromaticity $(\mathrm{H} / \mathrm{C})$ and polarity $(\mathrm{O} / \mathrm{C})$ of biochar and were calculated as 0.06 and 0.33 , respectively. PC biochar was highly carbonized at high temperature, and its low ash content (2.13 wt $\%)$ indicated the efficient thermal conversion process. The other physico-chemical characteristics of PC biochar are given in Table 1.

The surface properties of raw PC biochar were improved through the chemical modification, and a high BET surface area $\left(11.543 \mathrm{~m}^{2} \mathrm{~g}^{-1}\right)$ of Zn-loaded PC biochar was observed as compared to raw PC biochar $\left(6.598 \mathrm{~m}^{2} \mathrm{~g}^{-1}\right)$.

The thermal properties of raw and Zn-loaded biochars are illustrated in Fig. 1. Derivative thermo-gravimetric (DTG) curve of raw PC biochar revealed two exothermic peaks corresponding to two weight loss steps at 330 and $480{ }^{\circ} \mathrm{C}$, respectively, whereas only one exothermic peak at $480{ }^{\circ} \mathrm{C}$ was observed in case of Zn-loaded PC biochar. The first weight loss step was associated with the decomposition of hemicellulose and cellulose fractions following lignin degradation in second weight loss step. The devolatilization of organic matters took place between 250 and $550{ }^{\circ} \mathrm{C}$ with a maximum weight loss at $480{ }^{\circ} \mathrm{C}$, showing a sharp decrease in biochar weight. In case of $\mathrm{Zn}$ -
Fig. 1 The TG (a) and DTG (b) curves of raw and Zn-loaded pine cone biochar

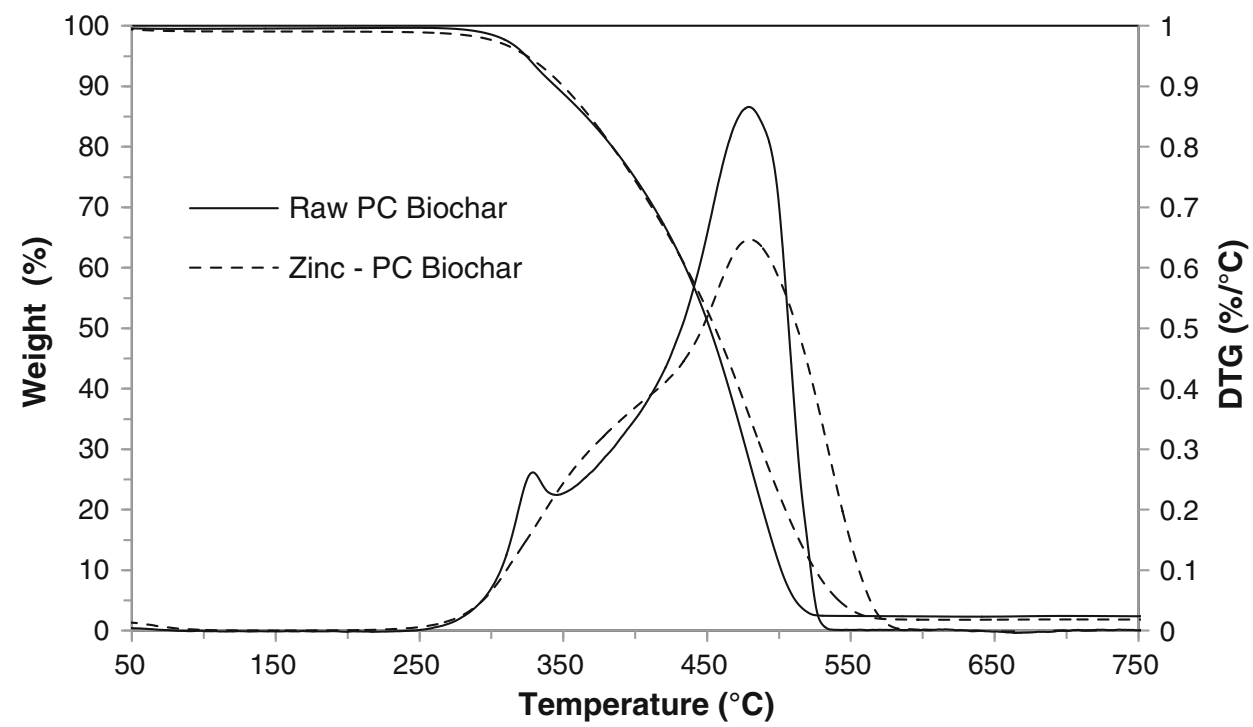


Fig. 2 The FTIR spectra of raw and $\mathrm{Zn}$-loaded pine cone biochar

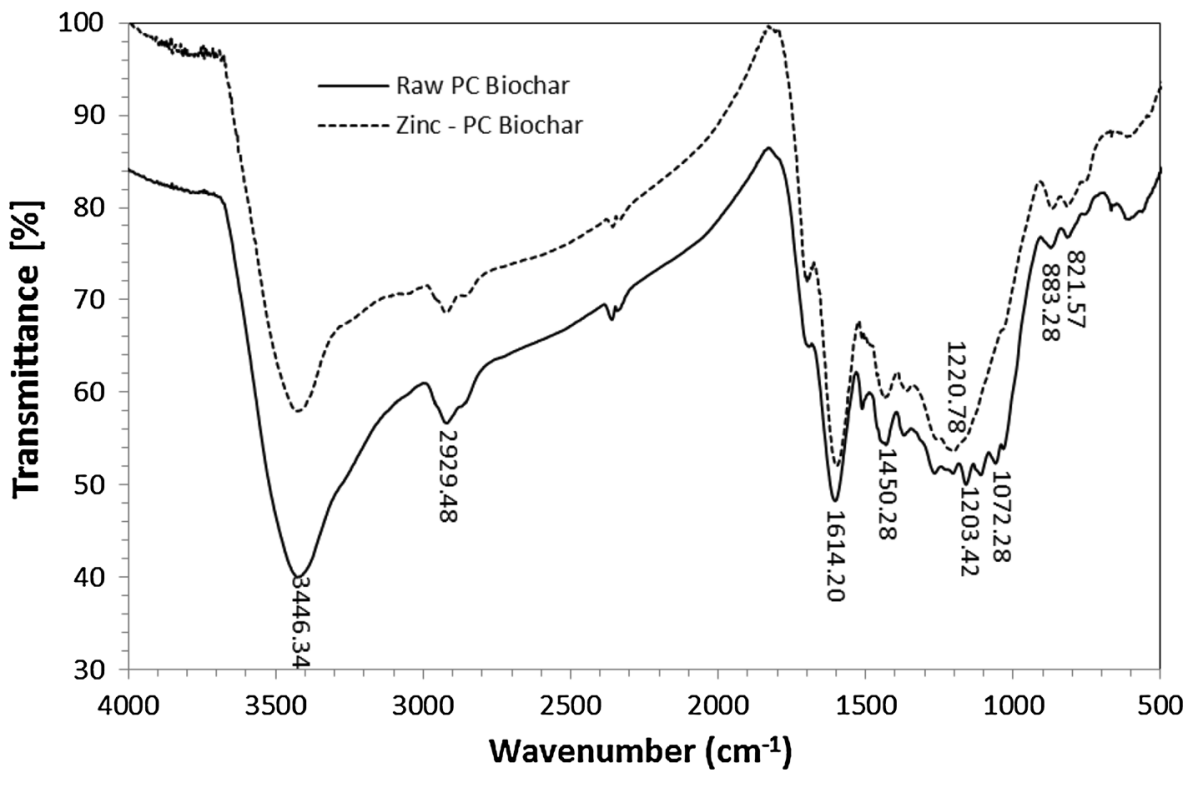

loaded PC biochar, the absence of first exothermic peak at $330{ }^{\circ} \mathrm{C}$ indicated the decomposition of cellulosic and hemicellulosic fractions during the surface modification process. Similar findings have been reported during the pyrolysis of rice husks and apricot stones (Sentorun-Shalaby et al. 2006; Williams and Besler 1993).

The FTIR spectra of raw and Zn-loaded biochar are illustrated in Fig. 2. Broad absorption bands in between 3,000 and $3,600 \mathrm{~cm}^{-1}$ were observed with a maximum peak at $3,434.34 \mathrm{~cm}^{-1}$ which can be assigned to the $\mathrm{O}-\mathrm{H}$ stretching vibrations of hydrogen bonds. Spectra band observed at $2,929.4 \mathrm{~cm}^{-1}$ represents the aliphatic $\mathrm{C}-\mathrm{H}$ group. Both raw and $\mathrm{Zn}$-loaded PC biochar exhibit the peaks at around $1,614.20 \mathrm{~cm}^{-1}$ which can be ascribed to the $\mathrm{C}=\mathrm{O}$ asymmetric stretching of ketones, aldehydes, lactones, or carboxyl groups (Momcilovic et al. 2011). The peaks in between 1,517.78-1,450.28 $\mathrm{cm}^{-1}$ represent the presence of aromatic rings or rings with $\mathrm{C}=\mathrm{C}$ bonds. Besides, the peaks in between $1,203.42-1,072.28 \mathrm{~cm}^{-1}$ are attributed to the $\mathrm{C}-$ $\mathrm{O}$ stretching groups of carboxylic acid or due to the coupling of the stretching band of $\mathrm{C}-\mathrm{N}$, and the bending band of N-H ( $\mathrm{Li}$ and Bai 2006; Martinez et al. 2006). Finally, the peaks in between 900 and $800 \mathrm{~cm}^{-1}$ were corresponding to the $\mathrm{C}-\mathrm{H}_{n}$ aliphatic or aromatic bonds (Blazquez et al. 2012). The treatment of $\mathrm{PC}$ biochar with $\mathrm{Zn}\left(\mathrm{NO}_{3}\right)_{2}$ resulted in the disappearance of peak at $1,220.78 \mathrm{~cm}^{-1}$ and the appearance of multiple peaks in between 1,203.42 and $1,072.28 \mathrm{~cm}^{-1}$. It can be demonstrated that the decomposition of hemicellulose and lignin components at high temperature leads to the breakage and rearrangement of stronger bonds in aromatic rings and carboxyl groups, with the evolution of additional $\mathrm{N}=\mathrm{O}$ from $\mathrm{Zn}\left(\mathrm{NO}_{3}\right)_{2}$ modification (Srinivasan and Ganguly 1991).
Figure 3a, c shows the morphology and surface characteristics of raw and Zn-loaded PC biochar, respectively, before the adsorption. Similarly, Fig. 3b, d illustrates the surface texture and morphology of raw and $\mathrm{Zn}$-loaded PC biochar, respectively, after the adsorption of As(III) from aqueous solution. The surface texture and morphology of both raw and modified biochars were different from one another. After the adsorption, the pores appearing on the surface have a fewer dimensions with smoother surface as compared to that before the adsorption. It is noteworthy that the chemical treatment of adsorbent has attributed the formation of porous structure that leads to an increase in internal surface as well as adsorption capacity (Zhang and Itoh 2005; Ofomaja et al. 2010).

\section{Effect of $\mathrm{pH}$ on adsorption}

Initial $\mathrm{pH}$ of the aqueous solution plays an important role in controlling the amount of As(III) adsorption onto the surface of biochar. Figure 4 represents the effect of varying $\mathrm{pH}$ on the removal efficiency of As(III) from the aqueous solution. Maximum adsorption capacity of As(III) was observed in the $\mathrm{pH}$ range of 2.0 and 4.0 for both raw and Zn-loaded PC biochars followed by a decrease with increase in the $\mathrm{pH}$ from 4.0 to 12.0 . At $\mathrm{pH} 2.0$, maximum As(III) adsorptive removal capacity of 5.3 and $7.0 \mu \mathrm{g} \mathrm{g}^{-1}$ onto raw and $\mathrm{Zn}$-loaded PC biochars, respectively, were observed. Mohan et al. (2007) have reported maximum As(III) adsorption onto the biochar derived from oak bark, oak wood, pine bark, and pine wood in the $\mathrm{pH}$ range 2.0 to 4.0. The data from the Fig. 4 indicated that the Zn-loaded PC biochar was more efficient compared to the raw PC biochar for As(III) adsorption. The adsorption of As(III) on 

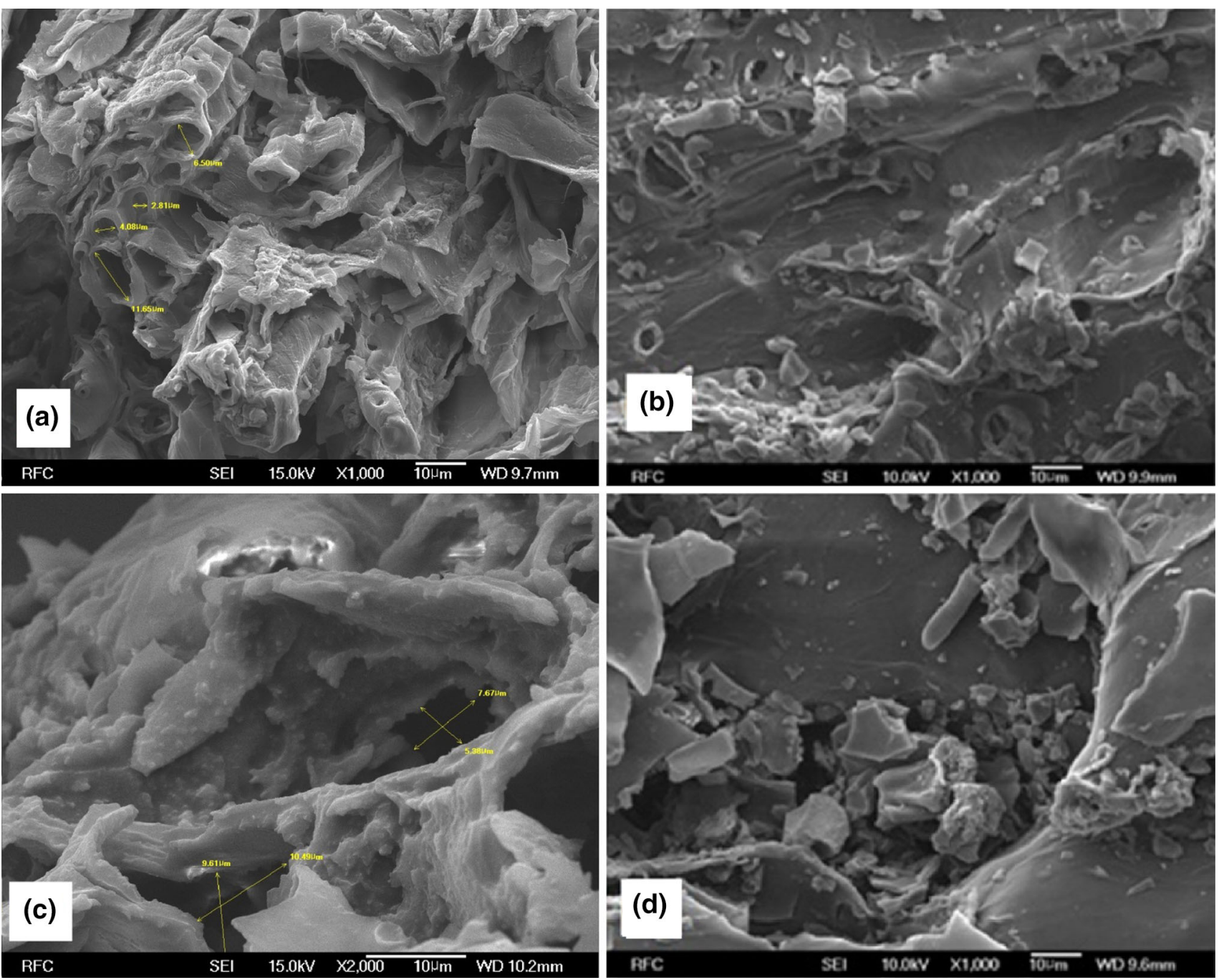

Fig. 3 The SEM micrographs of raw PC biochar samples before and after adsorption of arsenic(III) (a, b), and Zn-loaded PC biochar samples before and after adsorption of arsenic (III) (c, d), respectively

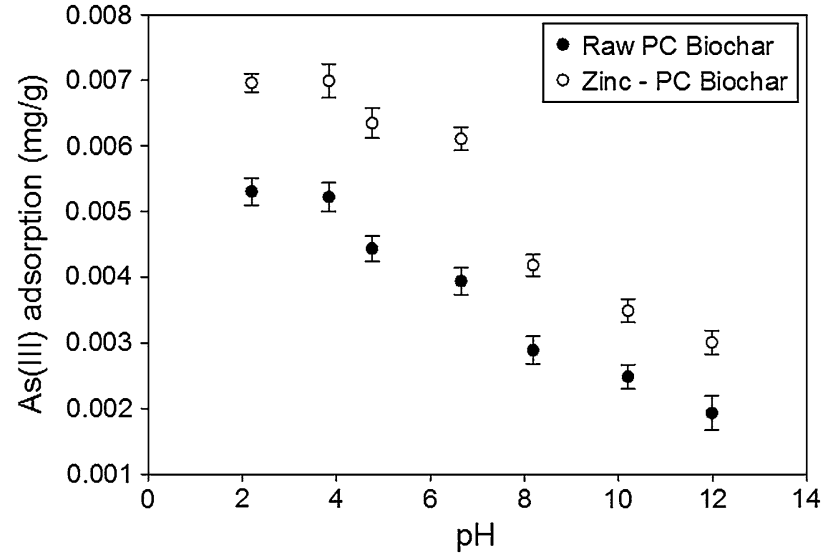

Fig. 4 The effect of pH on As(III) removal onto raw and Zn-loaded PC biochar

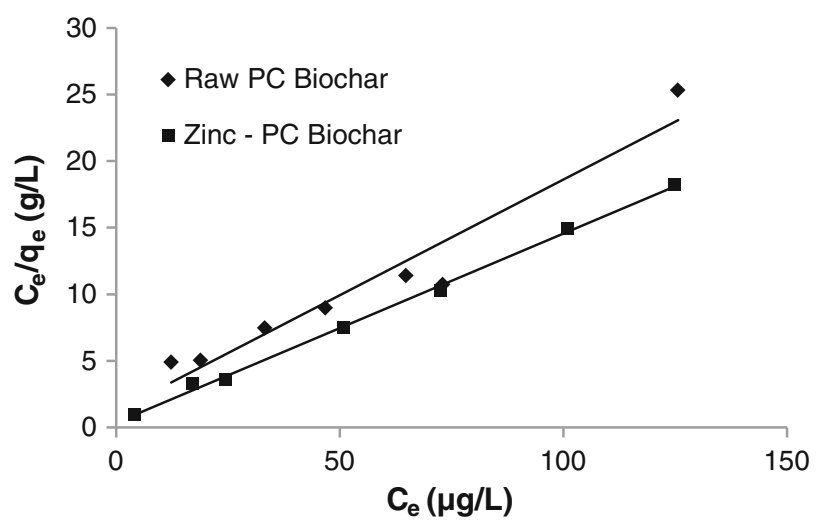

Fig. 5 Langmuir plot for the adsorption of arsenic by raw and $\mathrm{Zn}$ loaded pine cone biochar 
PC biochar with or without metal was dependent on the arsenic valence and the $\mathrm{pH}$ of the solution. In the aqueous solution, As(III) exists either as neutral or slightly charged species which is not readily oxidized at basic $\mathrm{pH}$ values. Hence, its uptake at high $\mathrm{pH}$ would be obviously low (Pattanayak et al. 2000). Physical adsorption was mainly responsible for the As(III) adsorption onto raw PC biochar, while chemisorption played additional role for As(III) adsorption onto Zn-loaded PC biochar (Rajakovic 1992) (Fig. 5).

It has been reported that $\mathrm{H}_{3} \mathrm{AsO}_{3}$ and $\mathrm{H}_{2} \mathrm{AsO}_{3}{ }^{-}$are the predominant $\mathrm{As}(\mathrm{III})$ species available in the aqueous solution in the $\mathrm{pH}$ range of 4 to 9.5 (Rajakovic 1992; Ayoob et al. 2007; Mondal et al. 2007). Both the surfaces of raw and $\mathrm{Zn}$-loaded $\mathrm{PC}$ biochars were positively charged up to their $\mathrm{pH}_{\mathrm{PZC}}$ value of 4.66 and 4.03 , respectively, and the adsorption primarily occurred through the electrostatic attractions between the neutral/negative arsenic species and positively charged biochar surface. Furthermore, with the increase in $\mathrm{pH}$ up to 7.0, a decrease in adsorption of As(III) was observed which was mainly due to the Van der Waals interaction between the neutral arsenic species and biochar surface. Above the $\mathrm{pH} 7.0$, a sharp decrease in adsorption was observed due to the increase in electrostatic repulsion between the negative surface sites of adsorbent and the dominating negative arsenic species of $\mathrm{H}_{2} \mathrm{AsO}_{3}{ }^{-}$and $\mathrm{HAsO}_{3}{ }^{2-}$.

Therefore, the overall effect of $\mathrm{pH}$ on the pattern of arsenic removal onto both raw and Zn-loaded biochars within the $\mathrm{pH}$ range of $2-12$ was quite similar, though to different extent. The impregnation of $\mathrm{Zn}$ onto biochar surface resulted in the increase in positive charge intensity at acidic $\mathrm{pH}$ of 2-4 that favored the higher As(III) removal efficiency. The removal of arsenic is highly dependent on solution $\mathrm{pH}$ and is influenced by the surface charge of adsorbent, degree of ionization, and the nature of arsenic species in solution (Hlavay and Polyak 2005; Ayoob et al. 2007).

The following reaction mechanism might be involved in the As(III) adsorption onto Zn-loaded biochar (Payne and Abdel-Fattah 2005).

$\mathrm{Z}(\mathrm{A})-[\mathrm{Zn}-\mathrm{OH}]^{+}+($ads $) \mathrm{H}-\mathrm{OAs}(\mathrm{OH})_{2}$

For $\mathrm{As}(\mathrm{III})$ adsorption at $\mathrm{pH}<7$

$\mathrm{Z}(\mathrm{A})-\mathrm{Zn}-\mathrm{O}-\mathrm{H}^{+}+($ads $)-\mathrm{O}-\mathrm{As}(\mathrm{OH})_{2}$

For $\mathrm{As}(\mathrm{III})$ adsorption at $\mathrm{pH}>7$

In the aqueous solution, As(III) exists in various anionic forms, viz. $\mathrm{AsO}_{3}{ }^{3-}, \mathrm{HAsO}_{3}{ }^{2-}$, and $\mathrm{H}_{2} \mathrm{AsO}^{3-}$ especially at $\mathrm{pH}>9.0$, while it appear in a little dissociated form in the $\mathrm{pH}$ range of 6.0 to 9.0. The chemisorption of As(III) might occur through the formation of surface complexes between the soluble arsenic species and the surface hydroxyl groups

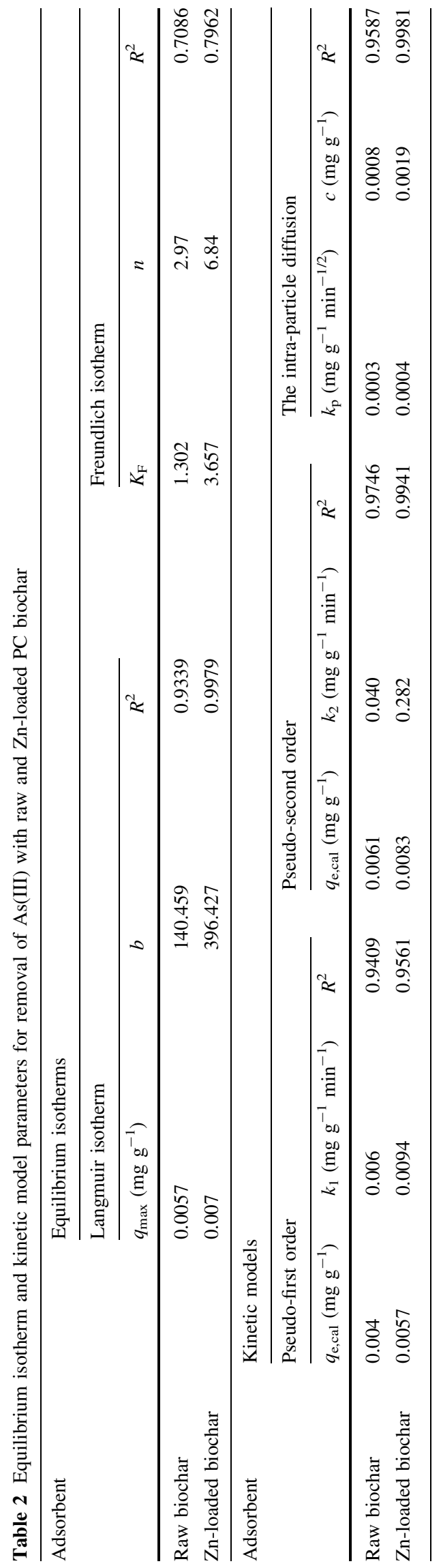


created by zinc modification (Payne and Abdel-Fattah 2005).

\section{Adsorption isotherms}

The performances of raw and Zn-loaded PC biochar were systematically evaluated using the Langmuir and Freundlich isotherm models by examining the distribution pattern of As(III) between the liquid phase and solid surface of PC biochar during the As(III) surface adsorption/chemisorption process. Table 2 shows that the experimental data of raw and Zn-loaded PC biochars were well fitted to the Langmuir isotherm with high $R^{2}(0.93$ and 0.99, respectively) as compared to the Freundlich model ( $R^{2}=0.70$ and 0.76 , respectively). The Langmuir isotherm represents the monolayer coverage of $\mathrm{As}$ (III) onto the surface of raw and Zn-loaded PC biochar. This isotherm assumes that the adsorption free energy is independent of both the surface coverage and the monolayer formation. The Langmuir monolayer coverage is defined by adsorption capacity $\left(q_{\max }\right)$, which was found to be $5.7 \mu \mathrm{g} \mathrm{g}^{-1}$ for As(III) adsorption on raw biochar and $7.0 \mu \mathrm{g} \mathrm{g}^{-1}$ on $\mathrm{Zn}$ loaded biochar with the initial adsorbate concentration of $100 \mu \mathrm{g} \mathrm{L}^{-1}$. In Langmuir isotherm model, $b$ represents the binding energy of the adsorption system and the degree of sorption affinity of adsorbate [As(III)] toward the PC

Table 3 Comparative evaluation of various low-cost adsorbents for arsenic(III) removal

\begin{tabular}{|c|c|c|c|c|c|c|c|}
\hline Adsorbents & $\begin{array}{l}\text { Type of } \\
\text { water }\end{array}$ & $\mathrm{pH}$ & $\begin{array}{l}\text { Arsenic } \\
\text { concentration }\end{array}$ & $\begin{array}{l}\text { Surface area } \\
\left(\mathrm{m}^{2} \mathrm{~g}^{-1}\right)\end{array}$ & Model & $\begin{array}{l}\text { Adsorption capacity } \\
\left(\mathrm{mg} \mathrm{g}^{-1}\right)\end{array}$ & References \\
\hline Pine wood char & $\begin{array}{l}\text { Drinking } \\
\text { water }\end{array}$ & 3.5 & $10-100 \mu \mathrm{g} \mathrm{L}^{-1}$ & 2.73 & Langmuir & 0.0012 & Mohan et al. (2007) \\
\hline $\begin{array}{l}\text { Char-carbon derived } \\
\text { from fly ash }\end{array}$ & $\begin{array}{l}\text { Aqueous } \\
\text { solution }\end{array}$ & 3.1 & $193-992 \mathrm{mg} \mathrm{L}^{-1}$ & 36.48 & NS & 89.2 & $\begin{array}{l}\text { Pattanayak et al. } \\
\text { (2000) }\end{array}$ \\
\hline Activated carbon & $\begin{array}{l}\text { Aqueous } \\
\text { solution }\end{array}$ & 5.4 & $193-992 \mathrm{mg} \mathrm{L}^{-1}$ & 43.4 & NS & 29.9 & $\begin{array}{l}\text { Pattanayak et al. } \\
(2000)\end{array}$ \\
\hline ZME $(\text { Oaxaca })^{\mathrm{a}}$ & $\begin{array}{r}\text { Ground } \\
\text { water }\end{array}$ & 4.0 & $0.1-4 \mathrm{mg} \mathrm{L}^{-1}$ & 51 & Langmuir & 0.0028 & $\begin{array}{l}\text { González et al. } \\
\text { (2001) }\end{array}$ \\
\hline $\begin{array}{l}\text { ZMS (San Luis } \\
\text { Potosi) }^{\mathrm{a}}\end{array}$ & $\begin{array}{r}\text { Ground } \\
\text { water }\end{array}$ & 4.0 & $0.1-4 \mathrm{mg} \mathrm{L}^{-1}$ & 22 & Langmuir & 0.017 & $\begin{array}{l}\text { González et al. } \\
\text { (2001) }\end{array}$ \\
\hline $\begin{array}{l}\text { Mn-minerals and } \mathrm{Fe}- \\
\text { oxides }\end{array}$ & $\begin{array}{l}\text { Drinking } \\
\text { water }\end{array}$ & 3.0 & $0.1-100 \mathrm{mg} \mathrm{L}^{-1}$ & 40.8 & NS & 14.7 & $\begin{array}{l}\text { Deschamps et al. } \\
\text { (2005) }\end{array}$ \\
\hline Biomass & $\begin{array}{l}\text { Aqueous } \\
\text { solution }\end{array}$ & 5.0 & $200 \mathrm{mg} \mathrm{L}^{-1}$ & NS & NS & NS & $\begin{array}{l}\text { Teixeira and } \\
\text { Ciminelli (2005) }\end{array}$ \\
\hline Fe modified AC & $\begin{array}{r}\text { Ground } \\
\text { water }\end{array}$ & $7.0-11$ & $50 \mu \mathrm{g} \mathrm{L}^{-1}$ & 1,200 & Langmuir & NS & $\begin{array}{l}\text { Payne and Abdel- } \\
\text { Fattah (2005) }\end{array}$ \\
\hline $\begin{array}{l}\text { Fe modified } \\
\text { Clinoptilolite }\end{array}$ & $\begin{array}{r}\text { Ground } \\
\text { water }\end{array}$ & $7.0-10$ & $50 \mu \mathrm{g} \mathrm{L}^{-1}$ & 40 & NS & NS & $\begin{array}{l}\text { Payne and Abdel- } \\
\text { Fattah (2005) }\end{array}$ \\
\hline Fresh biomass & $\begin{array}{l}\text { Ground } \\
\text { water }\end{array}$ & $6.0-8.0$ & $100 \mathrm{mg} \mathrm{L}^{-1}$ & NS & NS & 128.1 & Kamala et al. (2005) \\
\hline $\begin{array}{l}\text { Modified calcined } \\
\text { bauxite }\end{array}$ & $\begin{array}{r}\text { Ground } \\
\text { water }\end{array}$ & $\sim 7.0$ & $1-2 \mathrm{mg} \mathrm{L}^{-1}$ & NS & Freundlich & 1.362 & Ayoob et al. (2007) \\
\hline Activated Carbon ${ }^{\mathrm{b}}$ & $\begin{array}{l}\text { Drinking } \\
\text { water }\end{array}$ & 7.9 & $5-20 \mathrm{mg} \mathrm{L}^{-1}$ & 1,030 & Langmuir & 1.393 & $\begin{array}{l}\text { Budinova et al. } \\
\text { (2006) }\end{array}$ \\
\hline Iron oxide-coated sand & $\begin{array}{l}\text { Drinking } \\
\text { water }\end{array}$ & 7.6 & $100 \mu \mathrm{g} \mathrm{L}^{-1}$ & 10.6 & Langmuir & 0.041 & $\begin{array}{l}\text { Thirunavukkarasu } \\
\text { et al. (2003) }\end{array}$ \\
\hline Iron oxide-coated sand & $\begin{array}{l}\text { Ground } \\
\text { water }\end{array}$ & 7.5 & $100 \mu \mathrm{g} \mathrm{L}^{-1}$ & NS & Langmuir & 0.0285 & Gupta et al. (2005) \\
\hline Uncoated sand & $\begin{array}{l}\text { Ground } \\
\text { water }\end{array}$ & 7.5 & $100 \mu \mathrm{g} \mathrm{L}^{-1}$ & NS & Langmuir & 0.0056 & Gupta et al. (2005) \\
\hline Raw PC biochar & $\begin{array}{l}\text { Aqueous } \\
\text { solution }\end{array}$ & 4 & $100 \mu \mathrm{g} \mathrm{L}^{-1}$ & 6.59 & Langmuir & 0.0057 & This study \\
\hline $\begin{array}{l}\text { Zinc-loaded PC } \\
\text { biochar }\end{array}$ & $\begin{array}{l}\text { Aqueous } \\
\text { solution }\end{array}$ & 4 & $100 \mu \mathrm{g} \mathrm{L}^{-1}$ & 11.54 & Langmuir & 0.0070 & This study \\
\hline
\end{tabular}

$N S$ not specified, $A C$ activated carbon, $P C$ pine cone

${ }^{a}$ Derived from natural zeolites, volcanic stone, and cactaceous powder

${ }^{\mathrm{b}}$ Carbon A, from Olive Pulp and Olive Stones 
biochar. A high affinity of Zn-loaded biochar $(b=396.43)$ toward As(III) species was observed when compared to the affinity of raw PC biochar $(b=140.46)$.

The essential characteristic of Langmuir isotherm is represented by a dimensionless separation factor $\left(R_{\mathrm{L}}\right)$ which represents the ratio of the unused adsorbent capacity to the maximum adsorbent capacity (Ayoob et al. 2007). This is given by the Eq. (9):

$$
R_{\mathrm{L}}=\frac{1}{1+b C_{0}}
$$

where $C_{0}$ is the initial $\mathrm{As}(\mathrm{III})$ concentration $\left(\mathrm{mg} \mathrm{L}^{-1}\right)$ and $b$ is the Langmuir isotherm constant. In this study, the value of $R_{\mathrm{L}}$ is calculated as 0.065 and 0.024 for As(III) adsorption onto raw and Zn-loaded PC biochar, respectively, indicating favorable adsorption of As(III) onto both raw and Zn-loaded PC biochar at ambient temperature $\left(25{ }^{\circ} \mathrm{C}\right)$.

The maximum As(III) adsorption capacity of raw and Zn-loaded PC biochar as obtained from the Langmuir model were 5.7 and $7.0 \mu \mathrm{g} \mathrm{g}^{-1}$, respectively, which is comparable to the findings of other researchers (Table 3 ). Almost similar uptake have been reported at equilibrium following the Langmuir model for Zeolite (ZME) (González et al. 2001), iron oxide-coated/iron oxide-uncoated sand (Gupta et al. 2005), and pine wood char (Mohan et al. 2007) (Table 3).

Kinetic modeling

Table 2 also represents the kinetic parameters evaluated by fitting the experimental data to pseudo-first-order, pseudosecond-order, and intra-particle diffusion models. It was observed that the pseudo-second-order model well fitted to the experimental data derived from raw and $\mathrm{Zn}$-loaded PC biochar with $R^{2}$ of 0.95 and 0.99 , respectively. A comparatively high $\mathrm{As}(\mathrm{III})$ uptake rate $\left(k_{2}\right)$ of $0.282 \mathrm{mg} \mathrm{g}^{-1}$ min was observed on Zn-loaded PC biochar when compared to the uptake rate of $0.040 \mathrm{mg} \mathrm{g}^{-1} \mathrm{~min}$ on raw PC biochar. Moreover, in both cases, $q_{\mathrm{e}, \text { cal }}$ values of (a)

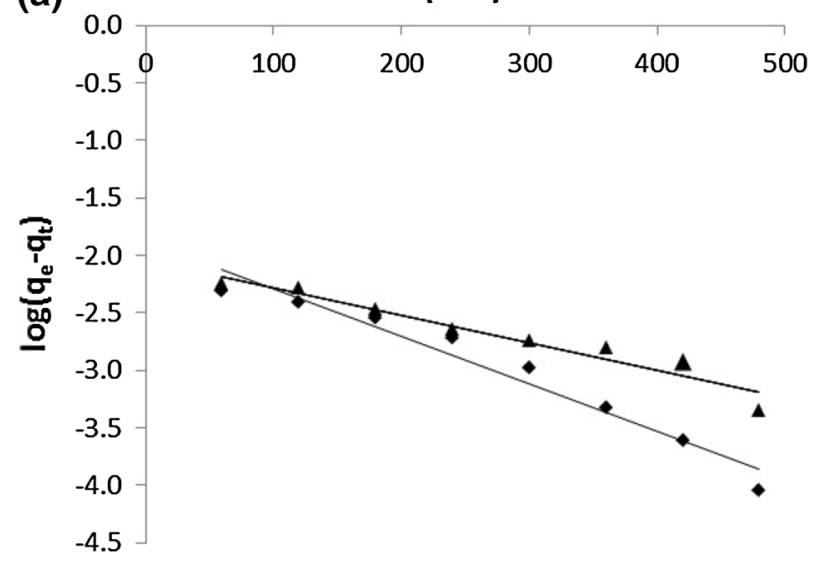

(b)

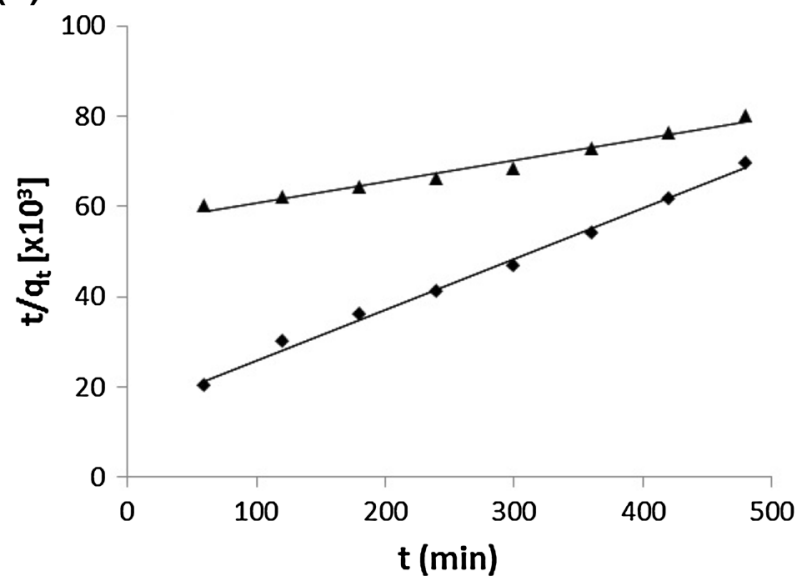

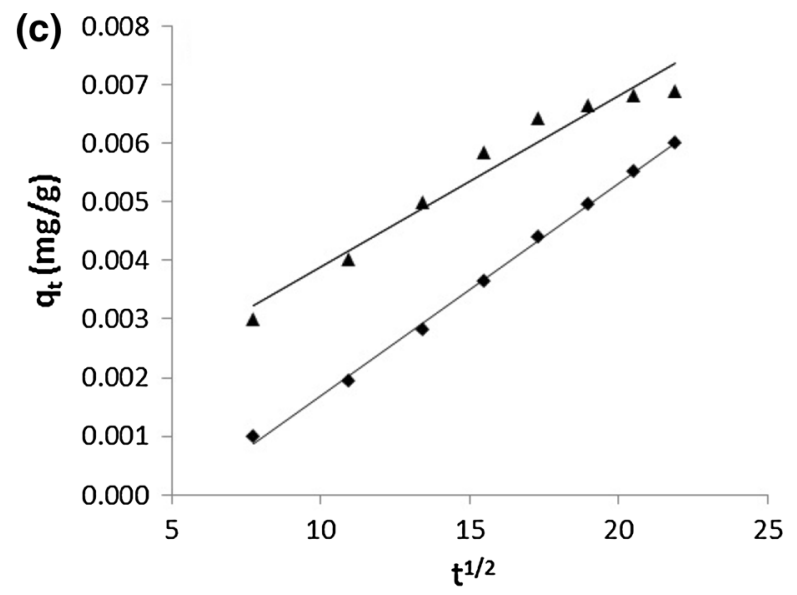

Fig. 6 Kinetic models for adsorption of As(III) onto raw $(\boldsymbol{\Delta})$ and Zn-loaded $(\bullet)$ PC biochar; a Pseudo-first-order, b Pseudo-second-order, and c the intra-particle diffusion 
Table 4 Thermodynamic parameters for removal of arsenic(III) at different temperatures

\begin{tabular}{lllll}
\hline Adsorbent & Temperature $(\mathrm{K})$ & $\Delta H^{\circ}\left(\mathrm{kJ} \mathrm{mol}^{-1}\right)$ & $\Delta S^{\circ}\left(\mathrm{kJ} \mathrm{mol}^{-1} \mathrm{~K}^{-1}\right)$ & -3.74 \\
\hline Raw PC biochar & 293 & & & -4.32 \\
& 303 & 13.25 & & -5.058 \\
Zinc-loaded PC biochar & 318 & & & -10.21 \\
& 293 & & 0.141 & -11.62 \\
& 303 & 31.10 & & -13.74 \\
\hline
\end{tabular}

0.0061 and $0.0083 \mathrm{mg} \mathrm{g}^{-1}$ were very close to the experimental $q_{\text {e,exp }}$ values (Fig. 6a, b).

The intra-particle diffusion plot shows some degree of nonlinearity between $\mathrm{As}(\mathrm{III})$ uptake $(\mu \mathrm{g} / \mathrm{g})$ and $\mathrm{t}^{1 / 2}$ for adsorption on raw PC biochar (Fig. 6c). Here, As(III) uptake $\left(q_{\mathrm{t}}\right)$ occurred in two steps: a sharper exponential linear portion attributed to the diffusion of As(III) species to the external surface of raw PC biochar through boundary layer diffusion followed by the intra-particle diffusion as indicated by a second gradual linear portion (Fig. 6c) (Tsibranska and Hristova 2011). The rate of uptake of As(III) might be affected by the size of adsorbate molecules, its concentration and affinity toward adsorbent, distribution coefficients of As(III) in bulk, and the pore size distribution of adsorbent. The adsorption of As(III) on Znloaded PC biochar was mainly controlled by boundary layer diffusion as represented by a sharp linear plot, but some degree of intra-particle diffusion was also responsible as the plot do not pass through origin $(c=0.0019)$.

\section{Thermodynamic studies}

The entropy $\left(\Delta S^{\circ}\right)$ and enthalpy $\left(\Delta H^{\circ}\right)$ values of adsorption were obtained from a linear plot of $\log \left(q_{\mathrm{e}} / C_{\mathrm{e}}\right)$ versus $1 /$ $T$ using Eq. (8) under three temperature ranges at $293 \mathrm{~K}$, $303 \mathrm{~K}$, and $313 \mathrm{~K}$ (Table 4). The calculated free energy $\left(\Delta G^{\circ}\right)$ was negative which indicated the feasibility of the process and spontaneous nature of the adsorption process in both the cases of raw and $\mathrm{Zn}$-loaded biochar. The positive $\Delta H^{\circ}$ values (13.25 and $31.10 \mathrm{~kJ} \mathrm{~mol}^{-1}$ ) in case of raw and Zn-loaded biochar, respectively, indicated the exothermic nature of adsorption interaction. The positive values of $\Delta S^{\circ}$ (0.058 and $\left.0.141 \mathrm{~kJ} \mathrm{~mol}^{-1} \mathrm{~K}^{-1}\right)$ showed an increase in randomness at the solid/solution interface during the adsorption of $\mathrm{As}(\mathrm{III})$ on raw and Zn-loaded PC biochar, respectively.

\section{Conclusion}

This study examined the practicality of PC biochar (raw and $\mathrm{Zn}$-loaded) to use as promising adsorbents for the removal of As(III) from aqueous solution. Adsorptive removal of $\mathrm{As}$ (III) on raw and $\mathrm{Zn}$-loaded $\mathrm{PC}$ biochar were found to be consistent over an acidic $\mathrm{pH}$ range of 2-4, which decreased further with an increase in solution $\mathrm{pH}$. The adsorption capacity of As(III) was enhanced from 5.7 to $7.0 \mu \mathrm{g} \mathrm{g}^{-1}$ through surface modification of PC biochar by $\mathrm{Zn}\left(\mathrm{NO}_{3}\right)_{2}$ impregnation. Langmuir model was well fitted to the equilibrium data which revealed highly favorable monolayer As(III) adsorption onto raw/Zn-loaded PC biochar. Kinetic study indicated the pseudo-second-order As(III) adsorption that was controlled by boundary layer diffusion with some extent of intra-particle diffusion. Besides, the exothermic and spontaneous nature of As(III) adsorption onto raw and Zn-loaded biochar justifies its effectiveness as a low-cost adsorbent for $\mathrm{As}$ (III) removal from surface/ground water.

Acknowledgments This work was supported by the research funds from the University of Ulsan in South Korea during the financial year 2012-2013.

\section{References}

Ahmad M, Lee SS, Dou X, Mohan D, Sung JK, Yang JE, Ok YS (2012) Effects of pyrolysis temperature on soybean stover- and peanut shell-derived biochar properties and TCE adsorption in water. Bioresour Technol 118:536-544

Akter A, Ali MH (2011) Arsenic contamination in groundwater and its proposed remedial measures. Int J Environ Sci Technol 8:433-443

Argun ME, Dursun S, Karatas M, Guru M (2008) Activation of pine cone using Fenton oxidation for $\mathrm{Cd}(\mathrm{II})$ and $\mathrm{Pb}(\mathrm{II})$ removal. Bioresour Technol 99:8691-8698

Arias F, Sen TK (2009) Removal of zinc metal ion $\left(\mathrm{Zn}^{2+}\right)$ from its aqueous solution by kaolin clay mineral: a kinetic and equilibrium study. Colloids Surf A Physicochem Eng Asp 348:100-108

Ayoob S, Gupta AK, Bhakat PB (2007) Performance evaluation of modified calcined bauxite in the sorptive removal of arsenic(III) from aqueous environment. Colloids Surf A Physicochem Eng Asp 293:247-254

Ayrilmis N, Buyuksari U, Avci E, Koc E (2009) Utilization of pine (Pinus pinea L.) cone in manufacture of wood based composite. For Ecol Manag 259:65-70

Benyoucef S, Amrani M (2011) Adsorption of phosphate ions onto low cost Aleppo pine adsorbent. Desalination 275:231-236 
Blazquez G, Martin-Lara MA, Dionisio-Ruiz E, Tenorio G, Calero M (2012) Copper biosorption by pine cone shell and thermal decomposition study of the exhausted biosorbent. J Ind Eng Chem 18:1741-1750

Budinova T, Petrov N, Razvigorova M, Parra J, Galiatsatou P (2006) Removal of arsenic(III) from aqueous solution by activated carbons prepared from solvent extracted olive pulp and olive stones. Ind Eng Chem Res 45:1896-1901

Daus B, Wennrich R, Weiss H (2004) Sorption materials for arsenic removal from water: a comparative study. Water Res 38:2948-2954

Deschamps E, Ciminelli VST, Holl WH (2005) Removal of As(III) and $\mathrm{As}(\mathrm{V})$ from water using a natural $\mathrm{Fe}$ and $\mathrm{Mn}$ enriched sample. Water Res 39:5212-5220

Ghanizadeh G, Ehrampoush MH, Ghaneian MT (2010) Application of iron impregnated activated carbon for removal of arsenic from water. Iran J Environ Health Sci Eng 7:145-156

González MPE, Mattusch J, Einicke WD, Wennrich R (2001) Sorption on natural solids for arsenic removal. Chem Eng J 81:187-195

Gu Z, Fang J, Deng B (2005) Preparation and evaluation of GACbased Iron-containing adsorbents for arsenic removal. Environ Sci Technol 39:3833-3843

Guo H, Stüben D, Berner Z (2007) Arsenic removal from water using natural iron mineral-quartz sand columns. Sci Total Environ 377:142-151

Gupta VK, Mittal A, Krishnan L (2005) Adsorption of As(III) from aqueous solutions by iron oxide-coated sand. J Colloid Interface Sci 288:55-60

Hlavay J, Polyak K (2005) Determination of surface properties of iron hydroxide-coated alumina adsorbent prepared for removal of arsenic from drinking water. J Colloid Interface Sci 284:71-77

Kamala CT, Chu KH, Chary NS, Pandey PK, Ramesh SL, Sastry ARK, Sekhar KC (2005) Removal of arsenic(III) from aqueous solutions using fresh and immobilized plant biomass. Water Res 39:2815-2826

Kamsonlian S, Suresh S, Ramanaiah V, Majumder CB, Chand S, Kumar A (2012) Biosorptive behaviour of mango leaf powder and rice husk for arsenic(III) from aqueous solutions. Int $\mathbf{J}$ Environ Sci Technol 9:565-578

Karagöz S, Tay T, Ucar S, Erdem M (2008) Activated carbons from waste biomass by sulfuric acid activation and their use on methylene blue adsorption. Bioresour Technol 99:6214-6222

Li N, Bai R (2006) Highly enhanced adsorption of lead ions on chitosan granules functionalized with Poly(acrylic acid). Ind Eng Chem Res 45:7897-7904

Mafu LD, Msagati TAM, Mamba BB (2013) Adsorption studies for the simultaneous removal of arsenic and selenium using naturally prepared adsorbent materials. Int $\mathrm{J}$ Environ Sci Technol. doi:10.1007/s13762-013-0374-1

Mahmoodi NM, Hayati B, Arami M, Lan C (2011) Adsorption of textile dyes on pine cone from colored wastewater: kinetic, equilibrium and thermodynamic studies. Desalination 268:117-125

Mandal BK, Suzuki KT (2002) Arsenic round the world: a review. Talanta 58:201-235

Manju GN, Raji C, Anirudhan TS (1998) Evaluation of coconut husk carbon for the removal of arsenic from water. Water Res 32:3062-3070

Martinez M, Miralles N, Hidalgo S, Fiol N, Villaescusa I, Poch J (2006) Removal of lead(II) and cadmium(II) from aqueous solutions using grape stalk waste. J Hazard Mater 133:203-211

Mohan D, Pittman CUJ (2007) Arsenic removal from water/wastewater using adsorbents-a critical review. J Hazard Mater $142: 1-53$
Mohan D, Pittman CUJ, Bricka M, Smith F, Yancey B, Mohammad J, Steele PH, Franco MFA, Serrano VG, Gong H (2007) Sorption of arsenic, cadmium, and lead by chars produced from fast pyrolysis of wood and bark during bio-oil production. J Colloid Interface Sci 310:57-73

Momcilovic M, Purenovic M, Bojic A, Zarubica A, Randelovic M (2011) Removal of lead(II) ions from aqueous solutions by adsorption onto pine cone activated carbon. Desalination 276:53-59

Mondal P, Balomajumder C, Mohanty B (2007) A laboratory study for the treatment of arsenic, iron, and manganese bearing ground water using $\mathrm{Fe}^{3+}$ impregnated activated carbon: effects of shaking time, $\mathrm{pH}$ and temperature. J Hazard Mater 144: $420-426$

Muniz G, Fierro V, Celzard A, Furdin G, Sanchez GG, Ballinas ML (2009) Synthesis, characterization and performance in arsenic removal of iron-doped activated carbons prepared by modification with $\mathrm{Fe}(\mathrm{III})$ and $\mathrm{Fe}(\mathrm{II})$. J Hazard Mater 165:893-902

Ning P, Qiu J, Wang X, Liu W, Chen W (2013) Metal loaded zeolite adsorbent for hydrogen cyanide removal. J Environ Sci 25(4):808-814

Ofomaja AE, Naidoo EB, Modise SJ (2009) Removal of copper(II) from aqueous solution by pine and base modified pine cone powder as biosorbent. J Hazard Mater 168:909-917

Ofomaja AE, Naidoo EB, Modise SJ (2010) Biosorption of copper(II) and lead(II) onto potassium hydroxide treated pine cone powder. J Environ Manag 91:1674-1685

Pattanayak J, Mondal K, Mathew S, Lalvani SB (2000) A parametric evaluation of the removal of $\mathrm{As}(\mathrm{V})$ and $\mathrm{As}(\mathrm{III})$ by carbon-based adsorbents. Carbon 38:589-596

Payne KB, Abdel-Fattah TM (2005) Adsorption of arsenate and arsenite by Iron-treated activated carbon and zeolites: effects of $\mathrm{pH}$, temperature, and ionic strength. J Environ Sci Health 40:723-749

Peraniemi S, Hannonen S, Mustalahti H, Ahlgren M (1994) Zirconium-loaded activated charcoal as an adsorbent for arsenic, selenium and mercury. Fresenius J Anal Chem 349:510-515

Rajakovic LV (1992) The sorption of arsenic onto activated carbon impregnated with metallic silver and copper. Separ Sci Technol 27:1423-1433

Regmi P, Moscoso JLG, Kumar S, Cao X, Mao J, Schafran G (2012) Removal of copper and cadmium from aqueous solution using switchgrass biochar produced via hydrothermal carbonization process. J Environ Manag 109:61-69

Sen TK, Thi TT, Afroze S, Phan C, Ang M (2012) Removal of anionic surfactant sodium dodecyl sulphate from aqueous solution by adsorption onto pine cone biomass of Pinus radiate: equilibrium, thermodynamic, kinetics, mechanism and process design. Desalin Water Treat 45:263-275

Sentorun-Shalaby C, Ucak-Astarlioglu MG, Artok L, Sarici C (2006) Preparation and characterization of activated carbons by onestep steam pyrolysis/activation from apricot stones. Micro Meso Mater 88:126-134

Srinivasan SK, Ganguly S (1991) FT-IR spectroscopic studies of metal nitrates supported on a modified montmorillonite clay. Catal Lett 10:279-288

Teixeira MC, Ciminelli VST (2005) Development of a biosorbent for arsenite: structural modeling based on X-ray spectroscopy. Environ Sci Technol 39:895-900

Thirunavukkarasu OS, Viraraghavan T, Subramanian KS (2003) Arsenic removal from drinking water using iron oxide-coated sand. Water Air Soil Pollut 142:95-111

Tsibranska I, Hristova E (2011) Comparison of different kinetic models for adsorption of heavy metals onto activated carbon from apricot stones. Bulg Chem Commun 43(3):370-377 
Ucun H, Bayhan YK, Kaya Y (2008) Kinetic and thermodynamic studies of the biosorption of $\mathrm{Cr}(\mathrm{VI})$ by Pinus sylvestris Linn. J Hazard Mater 153:52-59

Urík M, Littera P, Ševc J, Kolenčík M, Čerňanský S (2009) Removal of arsenic (V) from aqueous solutions using chemically modified sawdust of spruce (Picea abies): kinetics and isotherm studies. Int J Environ Sci Techol 6:451-456

Varol EA, Putun AE (2012) Preparation and characterization of pyrolytic chars from different biomass samples. J Anal Appl Pyrol 98:29-36

Vaughan RLJ, Reed BE (2005) Modeling As(V) removal by a iron oxide impregnated activated carbon using the surface complexation approach. Water Res 39:1005-1014
Vazquez G, Alonso R, Freire S, Gonzalez-Alvarez J, Antorrena G (2006) Uptake of phenol from aqueous solutions by adsorption in a Pinus pinaster bark bed. J Hazard Mater B133:61-67

Williams PT, Besler S (1993) The pyrolysis of rice husks in a thermogravimetric analyser and static batch reactor. Fuel 72:151-159

Yang W, Kan AT, Chen W, Tomson MB (2010) pH-dependent effect of zinc on arsenic adsorption to magnetite nanoparticles. Water Res 44:5693-5701

Yi L, Fu-Shen Z, Fu-Rong X (2009) Arsenic(V) removal from aqueous system using adsorbent developed from a high ironcontaining fly ash. Sci Total Environ 407:5780-5786

Zhang F-S, Itoh H (2005) Iron oxide-loaded slag for arsenic removal from aqueous system. Chemosphere 60:319-325 